\title{
ПСИХОТРОПНЫЕ СВОЙСТВА НОВЫХ СТРУКТУРНЫХ АНАЛОГОВ ИЗОТИОБАРБАМИНА
}

\author{
Л.А.Саблина', М.Ю. Воронцов', Д.С. Шейкин², Л.А. Брунилина² \\ ${ }^{1}$ Научный центр инновационных лекарственных средств с опытно-промышленным \\ производством, ВолгГМУ, 400131, Россия, Волгоград, площадь Павших Борцов, д. 1. \\ ${ }^{2}$ ФГБОУ ВО Волгоградский государственный технический университет, \\ 400005, Россия, Волгоград, пр. имени Ленина, 28.
}

DOI: 10.19163/MedChemRussia2021-2021-270

E-mails: fibfuv@mail.ru; maxim.nawrozkij@vstu.ru

Астения является распространенным состоянием и лежит в основе депрессивных и тревожных расстройств, которые лидируют среди психических заболеваний[1]. Некоторые производные тиобарбитуровой кислоты могут увеличивать физическую работоспособность в неблагоприятных условиях, что отмечено уизотиобарбамина. Это делает целесообразным продолжить поиск психотропных эффектов среди новых веществ этой группы [2].

Исследование психотропной активностив ряду новых структурных аналогов изотиобарбамина выполнено на крысах-самцах линии Wistar, соединения вводили однократно перорально за 60 мин до тестов, в эквимолярных дозах, определенных как наиболее эффективные в предварительных экспериментах. Психотропную активность оценивали в тестах «Открытое поле», «Принудительное плавание с грузом», «Приподнятый крестообразный лабиринт», «Конфликтная ситуация вариант Vogel» и «Принудительное плавание по Porsolt»[3].

Среди исследуемых новых структурных аналогов изотиобарбамина все соединения оказали сопоставимое с изотиобарбамином актопротекторное действие в тесте «Принудительное плавание с грузом», при этом по результатам теста «Открытое поле» все соединения не проявляли седативного или психостимулирующего действия. При дальнейшем исследовании у некоторых структур было выявлено сопоставимое с фенибутом анксиолитическое действие в тестах «Приподнятый крестообразный лабиринт» и «Конфликтная ситуация вариант Vogel» или сопоставимое с флуоксетином антидепрессантное действие в тесте «Принудительное плавание по Porsolt».

Для производных изотиобарбамина характерен широкий спектр психотропной активности. Целесообразно продолжить поиск в ряду новых структурных аналогов изотиобарбамина средств для лечения астении, тревожных и депрессивных расстройств.

\section{Литература}

[1] N. Watanabe, R. Stewart, R. Jenkins, D. K. Bhugra, T.A. Furukawa, JPsychosomRes, 2008, 64, 357.

[2] И. А. Новаков, Д. С. Шейкин, В. В. Чапуркин, М. Б. Навроцкий, А. С. Бабушкин, Я. П. Кузнецов, Е. А. Ручко, В. В. Качала, А. Ю. Марышев, Д. Шольц, Химия гетероцкл. соединений, 2020, 67.

[3] А.Ю. Вигоров, В.П. Краснов, И.А. Низова и др. Доклады Российской академии наук. Химия, науки о материалах. 2020, 494(1), 9-14. 